\title{
The Expression of English And in the Indonesian Language
}

\author{
Hermawati Syarif \\ FBS-UNP Jln. Prof. Dr. Hamka - Air Tawar, Padang 25131, Sumatera Barat, Indonesia \\ E-mail: hermawati_sy@yahoo.com
}

\begin{abstract}
It analyzes the expression of English and in Indonesian. The analysis is by using distributional method with the suited techniques. The finding shows that the expression of and in the Indonesian construction varies, but dan is the most frequently used. The Indonesian construction containing the equivalence of and as well as the meanings of its relationship in Indonesian also varies, that is having similarity and differences. The similarity is on its position in phrasal and clausal construction, while the difference is on the construction of voice, such as the English active transitive, expressed in passive transitive in Indonesian. The English emphatic meaning may change into the terminative meaning in Indonesian. The expression of AND in Indonesian is like lalu, sedangkan, bahkan, akibatnya, namun, sehingga, karena.
\end{abstract}

Keywords: Conjunction, Construction, Relationship meaning, Constituent, Equivalence

\section{Introduction}

And, different from other simple English conjunctions, is amenable and can conjoin the full range of constituents. It also has full range of meanings related to the context it is in. It is pictured out from many linguists works, such as Quirk's et. al. (1987), Schiffrin's, 1987), Murcia's \& Freeman's (1999), Berk's (1999), Halliday (2002). Quirk et. al. (1987: 927-929), for example, assert that and has various word orders in compound sentences. It goes to any kind of compund constituent of text, from the small lexical elements to sentences (Berk,1999: 218). Semantically, the function of and (Murcia \& Freeman,1999) as the reflection of logical relation may determine the meaning in different constructions functionally. Various functions of and which imply the meanings become the central focus in the discussion albeit the generic meaning of and is additive (Halliday and Mattlessen, 1999). The uniqueness of and is clearly seen in its colloquial use of English as I analysed in the English novels. This fact influences its expression in Indonesian. As a matter of fact, a lot of information, namely, any kind of English books, English novels needs to be translated into Indonesian. And the use of and cannot be avoided in texts read. The behaviour of and in English which is compared to its equivalence in Indonesian needs comprehending of translation and meaning interpretation, namely from English to Indonesian. For the purpose of translation, it is very crucial to review the expression of and.

This article offers an analysis of the expression of English and in the Indonesian language. Different system of two languages creates their different constructions. The constructions of English utterances are translated in the way of the Indonesian constructions. The study on and in English comprehensively is connected to its expression in Indonesian. Thus, the syntactic and semantic behaviour of and in English is taken as the focus of analysis, which is related to its equivalent expression in Indonesian. It is stated by the research question How is and expressed in Indonesian?

\section{Methodology}

It is a descriptive study with record review data (Seliger and Shohamy, 1989). Since the study involves two languages, that is English and Indonesian, the data gained were from both sources. The data sources are novels and popular as well as scientific textbooks. Both sorts of English data and their published Indonesian translation were selected randomly. To analyse the behaviour of and in the discourse, statements, related to extralinguistic features and text analysis refers to Quirk (1987: 931), Leech (1992: 62, Martin (1997: 5-19), Schiffrin (1987). The translational equivalance method is used to analyse the expression of and in the Indonesian construction (Djajasudarma, 1993: 58), so that differences and similarities of the behaviour of and with that of its Indonesian equivalence could be seen. It is used by the reason that certain construction in a language is not always expressed similarly to the construction in another language (Tadjudddin, 2004: 151-152). As an instance is that the active English construction that may be expressed in the Indonesian passive construction. 


\section{The Expression of $\boldsymbol{A N D}$ in the Indonesian Language}

\subsection{The Variations of the Expression of English And Equivalence in Indonesian}

And in English is expressed variously in Indonesian relying on the constituents it relates and when it emerges in the constituents combined. The data classification shows that from 467 times of and emergence, it is mostly expressed in dan in Indonesian, that is 301 times $(64,45 \%)$. This expression consists of identical constructions (297 times), and different constructions (4 times). The use of dan is mostly found in a popular textbook (non-fiction): Sincerity Described in the Qur'an (86,96\%) of the total source data. It apparently shows that popular textbooks, focussing on message and formal style of language, don't really need variation of the expression of and in the translation compared to the novels as fiction works (Djajasudarma, 1998) in her unpublished paper presented in the IIIrd Academic Seminar of Linguistics by Doctoral Program of Padjajaran University. The frequency of other expressions of English and are very much below the frequency of Indonesian dan. And expressed in Indonesian lalu with the variation of and, and then, and and afterward is noted 18 times $(3,85 \%)$, respectively followed by Indonesian dengan and sehingga, each of them is 7 times $(1,5 \%)$. Other expressions appear below the frequency of dengan and sehingga, that is terus, juga, and sedangkan. This variation is mostly found in the novel of The Naked Face (Sheldon, 1984), with 13 kinds, followed by the textbook of Principles of Pragmatics (Leech, 1983), 11 kinds. The fact can be understood since the novel of The Naked Face as a fiction work needs esthetique in using language, both, the source book and its translated book. It is supported by Tadjuddin (1998:6) in his unpublished paper presented in the IIIrd Academic Seminar of Linguistics by Doctoral Program of Padjajaran University Bandung, that in literary work, esthetical impression in expressing a translation of formulating discourse is very crucial. On the other hand, the expressions of and in the science textbook of Principles of Pragmatics in Indonesian is varied enough. It is assumed because of its nature as a language textbook that logically fulfilled all requirements of translating, expressing the message as well as selecting various words. Besides, English and in certain contexts is not always expressed explicitly in Indonesian. The data shows that 76 times of and (16,3\%) in the text, are not stated in Indonesian (in the translated version searched). It may be stated that Indonesian dan is elipped as the expression of English and (see Djajasudarma, 1998).

Based on the word class, the expression of and on form variation and and $+A d v$.Conj. in Indonesian can be grouped as in Table 1 (based on Alwi's et al., 2003 in the last page).

Eventhough there is a dual function, that is as conjunction and conjunctive adverbial, the form is only grouped in the category which frequently emerges.

And, as a coordinator of the English language, is apparently expressed in four kinds of connectives in Indonesian, that is, coordinator, subordinator, conjunctive adverbial, and preposition. The variation can be elaborated in the following sections.

\subsection{The Expression of And in the Indonesian Constructions}

From the translated data gained, the identical and different constructions combined by the equivalence of and in Indonesian are clearly seen. The profile of the English constructions with and in relation to its expression in Indonesian can be differed as (1) the construction with dan, (2) the construction without dan, and (3) the construction with dan from the English zero and construction. This profile is based on Song's (1986) opinion stated that the construction meaning with and can be understood in overt and covert performance.

Firstly, and in the English construction is expressed by dan in the Indonesian construction. Both and and dan are coordinators which have generic meaning of addition as it is stated by Martin (1992: 176), Collerson (1995: 97), and Berk (1999: 220-222). It is reasonable when and expressed in dan in Indonesian is the most frequently used. To know the expression constructed with dan, it is shown through analyzing the following data.

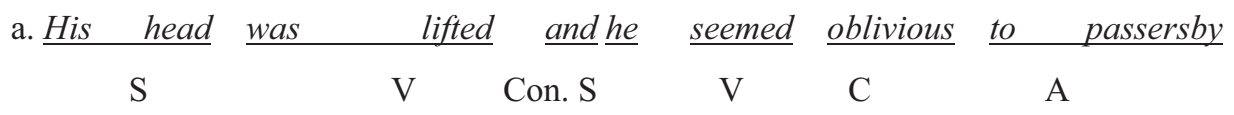

dia kepala aux. terangkat dan dia kelihatan terlupa pada orang-orang lewat who bumped against him.

yang menabrak melanggar dia

b. 'Kepalanya terangkat tinggi, dan tampaknya dia tidak mempedulikan

S

V C Con.

A

$\mathrm{S}$

$\mathrm{V}$ 
beberapa orang lewat menabraknya.'

$\mathrm{O}$

2. a. The doctor had told her that she should try it. And she had

det dokter telah mengatakan dia bahwa dia harus mencoba nya dan dia telah

promised that shewould. For the baby. And then, suddenly, as she

berjanji bahwa dia akan untuk det. bayi dan kemudian tiba-tiba sambil dia

sat there, she had an idea.

duduk di sana dia mendapat sebuah gagasan

b. 'Dokter tadi mengatakan bahwa dia harus terus mencoba untuk tetap makan.

Dan dia telah berjanji bahwa dia akan melakukan itu. Demi bayinya.

Kemudian, sambil masih duduk, dia tiba-tiba punya ide.'

In (1), English and (a) is expressed with dan (b) in Indonesian. Either and or dan combines two independent clauses, and functions as a serial event marker (Baker, 1996; Berk, 1998). It shows that the expression of English and is similar to Indonesian dan. However, the word order of these two kinds of combined sentences are different, that is SVCon.SVCA) in English and SVCCon.ASVO in Indonesian. It is interesting to know that in the second clause, the copulative verb seem is expressed in conjunctive adverbial tampaknya, and adjective oblivious with the function of $\mathrm{C}$ (complement) is expressed in active-transitive verb tidak mempedulikan (negative) in Indonesian. Tadjuddin's (2004: 151-152) saying that expressing the meaning of the utterances from one language to another language influences the word class and syntactic function used is met here. Furthermore, datum (2) is serial sentences marked by and at the beginning of sentence 2 and sentence 4 . The construction with and is identical to the translated construction in terms of its expression in Indonesian. The translator uses the identical word order to its original data. The different thing found is only the indirect object her which is not expressed in Indonesian. It could be understood that the absence of her is in terms of avoiding using word redundancy and having confusing meaning. It is like what Djajasudarma (1998:2) stated that the use of coreferent personal pronoun in the source language can cause confusion whenever both are translated into the target language. Lastly, in the fourth constituent, the translator tends to use kemudian in expressing and.

Different from the construction of data (1) and (2), the expression of the following data shows different constituents combined by and.
3. a. $\mathrm{He}$

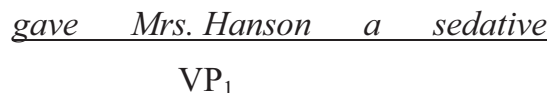
and called the family doctor.$$
\mathrm{VP}_{1}
$$
Con.
$\mathrm{VP}_{2}$

dia memberi nyonya hanson det. obat penenang dan memanggil det. keluarga dokter

b. 'Kemudian Nyonya Hanson diberinya obat penenang, dan dokter

$$
\mathrm{CCL}_{1} \text { Con. }
$$

keluarga diteleponnya.'

$\mathrm{CCL}_{2}$

4. a. All she had left was the jewelery, and that was carefully

$$
\mathrm{CCL}_{1}
$$

Con.

$\mathrm{CCL}_{2}$

semua dia telah meninggalkan cop. det perhiasan dan itu aux. dengan hati-hati

stowed in the vault.

disimpan dalam det penyimpanan

b. Barang berharga Bettina yang masih tersisa hanyalah koleksi perhiasannya,

$$
\mathrm{VP}_{1}
$$

dan aman tersimpan di kotak penyimpanan di bank.

Con. $\quad \mathrm{VP}_{2}$

5. a. But many have gravedoubts about the narrowness of thisparadigm's

$\mathrm{PP}_{1}$ 
tapi banyak mempunyai besar keraguan tentang det kesempitan dari ini paradigma poss. definition of language, and about the high degree of abstraction and

Con. $\quad \mathrm{PP}_{2}$

definisi dari bahasa dan tentang det tinggi tingkatdari abstraksi dan

idealization of data which it requires.
idealisasi dari data yang itu membutuhkan

b. 'Tetapi banyak ilmuwan sangat meragukan kebenaran definisi paradigma bahasa yang

Stc. 1

demikian sempitnya. Yang juga mereka pertanyakan ialah tingginya tingkat abstraksi dan

Stc. 2

idealisasi data yang dituntut oleh definisi seperti itu.'

In (3a) of the English datum, and combines active transitive VPs, while in the Indonesian expression (3b), it is coordinating clause (CCL) with passive clause construction. The construction of both English and Indonesian sentences with and follows the general theory of coordination, that is combining two or more similar constituents (Givon, 1984; Biber et al., 1999). It is likely that the translator strengthens the existence of English clause object Mrs. Hanson and the family doctor by topicalizying them in the form of passive clause (Nyonya Hanson diberinya..., dokter keluarga diteleponnya).

And in data (4a) combines CCLs, that is copulative $\mathrm{CCL}_{1}$ and passive construction of $\mathrm{CCL}_{2}$. In the Indonesian construction, however, and is expressed in dan that combines $\mathrm{VP}_{1}$ hanyalah koleksi perhiasannya and $\mathrm{VP}_{2}$ aman tersimpan di kotak penyimpanan di bank. This construction is as a result of subject elipped in the second clause.

Datum (5) shows that and combining $\mathrm{PP}_{1}$ about the narrowness of this paradigm's... and $\mathrm{PP}_{2}$ about the high degree of abstraction ... which functions as the object marker of grave doubts in sentence (5a) is expressed into two sentences ( $\left.\mathrm{Stc}_{1}\right)$ and $\left(\mathrm{Stc}_{2}\right)$ in (5b) with the marker of yang juga in place of and. The subject of sentence two of data (5b) is in form of dependent clause yang juga mereka pertanyakan. A sentence in English becoming two sentences in Indonesian is suited to Catford's opinion (1965) in Djajasudarma (1998:4) that one sentence in the source language is not always translated one sentence in the target language. However, the changes of its combined construction of PP (English) into sentences (Stc.) in Indonesian construction, in my opinion, is not so economical. It will be more economical when it is expressed by NPs combined construction, as in the following underlined constituents.

\section{'Tetapi banyak ilmuwan sangat meragukan kebenaran definisi paradigma \\ bahasa yang demikian sempitnya, serta tingginya tingkat abstraksi dan \\ idealisasi data yang dituntut oleh definisi seperti itu.}

To see the unity of the two NPs, and is expressed in serta in Indonesian. From the three data analysed, it is shown that the expression of and may change based on the grammaticality and lexicality in Indonesian (Alwi, 2003).

Secondly, zero marker is as the equivalence of and in the Indonesian construction. Beside having its explicit expression in Indonesian, and also expresses implicitly in the Indonesian construction. The following data show us its expressions.

6. a...the traffic light ambered its way to redand he stopped with the

det penyeberangan lampu kuning nya arah ke merah dan dia berhenti dengan det.

impatient crowd.

tidak sabar orang banyak

b. '... lampu penyeberangan ganti menjadi merah. Ø Dia pun berhenti bersama orang banyak yang tidak sabar.'

7. a. Carol looked at him amoment and then said enthusiastically,

carol memandang pada dia sebentar dan kemudian berkata sungguh-sungguh 
"I never thought of that."

saya tidak pernah memikirkan dari itu

b. 'Carol memandangnya sesaat. Ø Kemudian dengan sungguh-sungguh dia berkata, "Itu belum pernah saya pikirkan.""

Data (6) and (7) show that the English coordinating clause constructions with and are expressed in two sentences. In its expression in Indonesian, and is not explicitly translated. This case normally occurs in sentences for the sake of economical use and redundancy (Teschner \& Evans (2000). Nevertheless, to show the relationship between two sentences, the translator uses pun (Indonesian particle) after the subject of second sentence (6b) and conjunctive adverbial kemudian in initial position of sentence $2(7 \mathrm{~b})$, which can be regarded as markers. pun and kemudian cannot be regarded as the equivalence of and because the function of each is to strengthen the meaning of the subject dia (Alwi, 1992). However, pun, in relation to the two sentences of $6 \mathrm{~b}$, also indirectly marked this relationship. In data (7a), and cooccurs with the conjunctive adverbial then (to clarify the function of and) in the sentence, and in (7b), kemudian is an equivalence of the same word class in English, that is conjunctive adverbial then.

Let's take a look at the following datum.

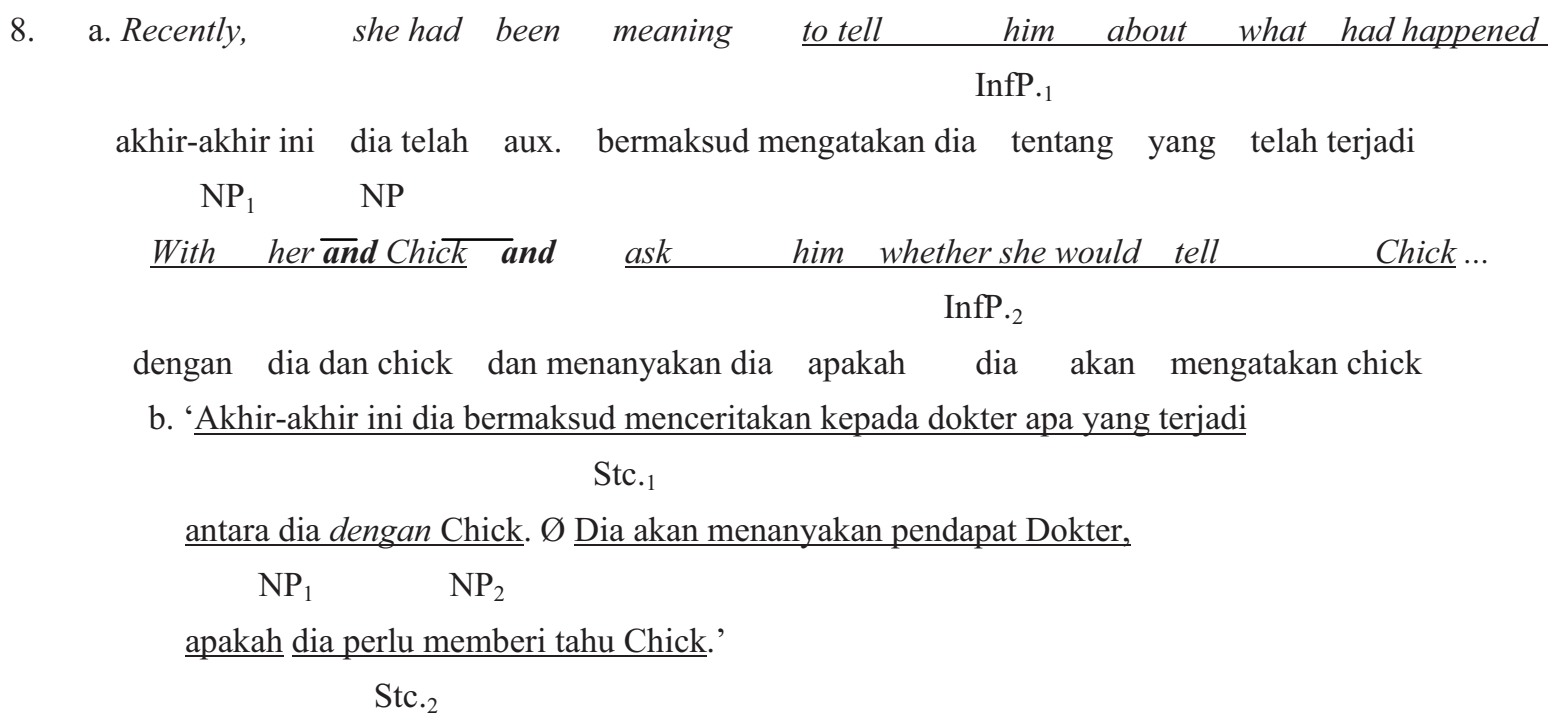

In (8a), there are two ands. The first is to combine $\operatorname{InfP}_{._{1}}$ and $\operatorname{InfP}_{2}$, and the second is to combine $\mathrm{NP}_{1}$ her and $\mathrm{NP}_{2}$ Chick (the part of Inf.P $\mathrm{P}_{1}$ ). In Indonesian, the expression of this construction changes. Firstly, the data in form of coordinating sentences with elipped subject in the second clause of English (instead of repeating the same constituent, ellipsis usually emerges in the text (Halliday, 1990)) becomes two independent sentences. There is no marker to indicate that the two sentences are related except coreference subject in both sentences, that is dia. This shows that the marker dan is absent at the initial position of second sentence. Secondly, and (coordinator) is expressed in dengan (preposition). This is as a combination of preposition antara ... dengan as corelative preposition (see Alwi, et al., 2003: 290). It is likely influenced by the use of preposition with at the beginning of NPs combination in (8a). As a matter of fact, the use of correlative conjunction antara...dan as an expression of between ... andit is more grammatical.

It is summarized that the construction with and in English may be expressed by zero marker in Indonesian. That is to show that expressing the meaning of literary work pays more attention to exploring the message explicitly (Tadjuddin's statement, 2004: 150). Thus, the variation of and's expression seems to be frequentitative, both in form and in word expression.

Beside this construction, ellipsis also occurs in the following data.

9. 
Datum (9a) is the coordinative construction with and between two clauses. The second constituent is the clause without verb. The verb can be found by analyzing the clause, that is the pain was in them (see Biber, et al, 1999). To express it in Indonesian, this coordinative clause combination cannot be retained. The construction consists of the combining coordinative clause and subordinative clause with zero conjunction. Yang as the marker functioning as a relator as well as the subject of CCL can be inserted in the Indonesian construction, like:

(9b)' 'Carol melihat mata Dokter yang memancarkan rasa sakit.'

Deleting the marker and in Indonesian also occurs in the following data.

10. She shook her head quickly "never". And then he lookedather

dia menggeleng poss. kepala dengan cepat tidak pernah dan kemudian dia melihat dia

verygently and searched her eyes.

sangat lembut dan meneliti poss. mata

'Bettina menggeleng dengan cepat, "tidak pernah". Ø Dokter itu lalu

memandangnya dengan sangat lembut, Ø tepat ke matanya.'

11. Of course, all these are deeds that must be accomplished by Muslims

tentu saja semua ini cop. perbuatan yang harus aux. dilakukan oleh para muslim

during their life times, and for which one may hope to attain great

selama poss. hidup waktu dan untuk apa seseorang dapatberharap mendapat besar

rewards on the Judgement Day.

penghargaan pada det. pembalasan hari

'Tentu saja semua itu adalah perbuatan yang harus dilakukan seorang muslim sepanjang hidup mereka Ø untuk mendapatkan balasan yang besar di hari pembalasan.'

And in (10) and (11) is not expressed in anything in Indonesian. However, from the relationship of two sentences in (10), the sequencial meaning of the two sentences is seen from the emergence of conjunction lalu as an equivalence of conjunctive adverbial then; on the other hand, VP searched her eyes is expressed to PP (tepat) ke matanya.To me, adverb tepat conveys the meaning of sequencial relationship. In data (11), of not emerging Indonesian word for and happens because of the changing of second constituent construction of finite clause for which one may hope to attain great rewards on the Judgement Day in English to Indonesian non-finite clause 'untuk mendapatkan balasan yang besar di hari pembalasan.' Nevertheless, this inexistence doesn't change the meaning, that is to state the relationship meaning of conditional to show reason-goal.

Thirdly, the construction with Dan in Indonesian is expressed without And in English. From the data analyzed, it is found that the construction without and in English is expressed with dan in Indonesian. However, there are data translated with dan as a replacement of zero conjunction in the second clause. The followings are those data.

12. a. Suddenly she stopped, stearing ahead of her.

tiba-tiba dia berhenti memandang lurus dari dia

b. Tiba-tiba langkahnya terhenti, dan ia memandang lurus ke depan.

13. a. Bunch sat back on her heel, frowning.

bunch duduk kembali pada poss. tumit mengerutkan dahi

b. Bunch berjongkok dan mengerutkan alisnya.

14. a. The man lay with eyesclosed, his breathing coming in slow,

det. lelaki berbaring dengan mata tertutup poss. nafas muncul dengan lambat

shallow fashion.

dangkal cara

b. 'Laki-laki itu terbaring dengan mata tertutup, nafasnya lambat dan tersengal- sengal.'

Data (12) and (13) are the constructions consisting of two clauses. Each of whose second clause is non-finite, that is ... stearing ahead of her (12) and frowning (13) These two clauses are not grammatical when preceded by 
and (Maurer, 2000). As we know, and can be used when both non-finite clauses Prtc.Ph. (V-ing) are paraphrased into the following finite clauses.

(12a') Suddenly she stopped, and she was stearing ahead of her.

(13a') Bunch sat back on her heel, and she was frowning.

It shows that and explicitly exists in construction (12a') and (13a'). In Indonesian, these non-finite English constructions are expressed in finite clauses by using conjunction dan in the translated data, like in (12b) dan (13b). As a matter of fact, the clause pairs of (12a) and (13a) show the activities which happen at the same time. Thus, the suitable translation for that, according to me, is by having conjunction sambil in the non-finite clause. From the data translated, it is apparently shown that the translator considered the meaning of dan identical to the meaning of sambil.

Unlike the two data, (14a) shows the complement part as a series of PP. ... in slow, shallow fashion. It implies the existence of and in between. It may be judged from the order of the clauses. The position of the two clauses could not possibly be exchanged. And in Indonesian, it is explicitly expressed by using conjunction dan (14b).

\subsection{The Meaning of And in the Indonesian Construction}

The meaning of and here is more related to "meaning -maximal" account, that is based on pragmatic study. The meaning of and is mostly as the use in its constituents relationship. There are two sorts of meaning differed as the expression of and in contextual relationship, that is identical and different relationship meaning.

\subsubsection{The Identical Relationship Meaning of And Expressed in Indonesian}

Since and is meaningful when it is in the construction, its expression in Indonesian varied based on its corresponding construction. In the following data, and has similar relationship meaning to its corresponding in Indonesian, such as bercampur and beserta.

15. a. Her tonewas equally compounded of reverent awe and triumph.

poss. nada aux. sama-sama ditambah dengan hormat rasa kagum dan kemenangan

b. 'Nadanya mengandung rasa hormat yang mendalam bercampur rasa bangga.'

16. a. Can a bird and the mechanics of its flight be a design as well?

dapat seekor burung dan det. mekanik dari poss. terbang cop. det. desain juga

b. 'Dapatkah seekor burung beserta cara terbangnya disebut sebagai rancangan pula?'

And in data (15) and (16) is expressed by the marker bercampur and beserta in Indonesian. It shows the description of relationship meaning of and in the source language (English). The constituents related by and indicates additive meaning showing the amount, and additional information. The constituents in (15a), reverent awe and triumph are a unity (it shows idiomatic expression), while the second constituent the mechanics of its flight in (16a) adds the information to the first constituent a bird (see Berk, 1999: 220). And with additive meaning showing the amount, which is expressed by the marker bercampur in data (15b), mostly shows closer related constituents of rasa hormat yang mendalam and rasa bangga compared to beserta in data (16b) which shows the relationship meaning of additional information of seekor burung and cara terbangnya. Thus, the expressions of equivalent meaning of and in Indonesian are bercampur and beserta.

The next data show the expression of equivalent and having sequencial relationship meaning in Indonesian.

17. a. The men moved awayfrom the bench and Carol heard her name called. det. para lelaki bepindah jauh dari det. bangku dan carol mendengar poss. nama dipanggil

b. 'Laki-laki itu berpindah dari bangku. Akhirnya, Carol mendengar namanya dipanggil.'

(a)

18. a. I took it out

(a) (b)

and I sewed it up again properly with a different thread

saya ambil itu keluar dan saya jahit itu part. lagi baik-baik dengan sehelai berbeda benang

that matched.

yang cocok 


\section{b. Kukeluarkan lalu kujahit lagi baik-baik dengan benang yang sewarna.}

(a)

(b)

In the context of (17a) and (18a), and has sequencial relationship meaning. It is seen from the contexts of each pair of constituents that shows chronological events. In both source and translated data, constituent (a) is the activity done before constituent (b); thus, their position cannot be changed. Both pairs of the data show that and and its equivalence in Indonesian has contextually sequencial relationship meaning (Quirk, 1987). It is also shown by the equivalence of and in Indonesian, akhirnya (17b) and lalu (18b). In another data, it is found that kemudian (Indonesian) also has sequencial relationship meaning (Sugono, 1995: 121-125).

Concessive relationship meaning of and expressed in Indonesian is seen in the following.

19. a. The man started to turn his head to see who had hit him,

(a)

det. lelaki mulai menolehkan poss. kepala untuk melihat siapa telah memukul dia and to his surprise, his knees began to buckle.

(b)

dan ke poss. heran poss. lutut mulai melemas

b. 'Laki-laki berjas hujan kuning ini mulai menoleh untuk melihat siapa yang

(a)

memukulnya, tetapi dia merasa heran karena lututnya lemas dan menekuk.'

(b)

In datum (19a), the second constituent, initiated by to his surprise indicates that the constituent of sentence (b) is different from expected. Constituent (a) The man started to turn his head to see who had hit him, is expected to be followed by the utterance, like and the big man stood in front of him in constituent (b), not his knees began to buckle. Then, as the relator of the two constituents, and automatically has concessive relationship meaning because it shows contrast expectation (Quirk, 1987; Comrie, 1989). Moreover, in Indonesian, data (19b) as the equivalent expression of (19a), the same thing happens. Concessive relationship meaning in the utterance is explicitly represented by tetapi as the equivalence of and. In Indonesian, tetapi is one of connectives stating concessive relationship meaning (Gianto, 1983).

In the following data, and shows the different relationship meaning from the preceded data.

20. a...., all of these systems are created withoutflaw and hence,

(a)

semua dari ini sistem-sistem aux. diciptakan tanpa cacat dan karenanya
the creature lives on.

(b)

det makhluk hidup terus

b. ' $\ldots$, seluruh sistem ini diciptakan tanpa cacat, sehingga makhluk ini tetap bertahan.'

(a)

(b)

21. a..., it is notoriously difficult to exclude the way meaning varies from context

(a)

imp. cop. terkenal sulit mengeluarkan det. cara makna berubah dari konteks

to context, and so semantics spills over into pragmatics.

(b)

ke konteks dan karenanya semantik masuk part. dalam pragmatik

b. '..., semakin tampak betapa sulitnya memisahkan makna dari konteksnya,

karena makna itu berbeda dari konteks yang satu ke yang lain. Akibatnya

ialah semantik masuk ke dalam pragmatik.' 
Both in data (20), and (21), constituent (a) is the reason of having constituent (b) initiated by and as the result of constituent (a). In (20a), and cooccurs with conjunctive adverbial hence and in (21a) with so, both of which strengthen the relationship meaning of reason emerged by and. Since it sums up the events, and in both data functions as a conclusion event marker (see Rusdi, 2000). The same meaning also occurs in its expression in Indonesian, which is represented by sehingga (20b) and akibatnya (21b). Both are the variation of the expression of and with the same meaning in Indonesian.

\subsubsection{The Relationship Meaning of And Expressed in Non- Dan in Indonesian}

The relationship meaning created by and may rely on the frequency of and emerged in a construction. Thus, the possibility of having different relationship meaning in its expression may be seen in the following data.

22. a ...she suddenly became aware of her nakedness and went in and put on

dia tiba-tiba menjadi sadar pada poss. ketelanjangan dan masuk dan memakal

his pajamas.

poss. piama

b. ... tiba-tiba Carol menyadari ketelanjangannya, lalu dia cepat-cepat masuk

untuk memakai piayama.

23. a. They talked about Mao Tse-tung and hula hoops and the Pill. And

having a mother and father who had never been married.

b. 'Mereka membicarakan Mao Ze Dong, hula hop, dan pil anti hamil. Mereka

juga berbicara tentang memiliki ayah dan ibu yang tidak pernah menikah.'

In data (22a) and (23a) and has the emphatic relationship meaning, namely showing more than two close relationship constituents (Gianto, 1983; Murcia-Freeman, 1999). In (22a), for example, three constituents, that is the state of behaviour she suddenly became aware of her nakedness, the activities of went in and put on his pajamas done by she show the very close relationship. On the other hand, in its expression in Indonesian, the first and is expressed with lalu and the second with untuk (22b). It is shown that lalu has sequencial meaning in relation to two first constituents, while untuk has conditional (reason-goal) meaning in relation to constituent 2 and 3. In (23a), three topics talked are combined by and in between each pair of constituents. It also indicates emphatic meaning, which shows strong relationship among the four main topics talked. In Indonesian, and is expressed in dan that appears once in initial position of final constituent combined. The utterance consists of a series of topic focuses, namely arguments ended by dan. The relationship meaning shown by dan in the utterance, however, is terminative (see Gianto, 1983). The analysis shows that the equivalence of and expressed in Indonesian in the two data has different relationship meaning from the one in English. Principally, the whole expression doesn't influence the meaning of contextual utterance, but influences the sense of the language. Unlike the two data mentioned, data (24) has two possible relationship meanings of and.

24. a. Mrs Mundy had a stroke about a week ago, and

(a)

nyonya mundy mengalami sebuah kelumpuhan kira-kira satu minggu lalu dan

the old man is been very ill with pneumonia.

(b)

det tua lelaki telah cop. sangat sakit karena pneumonia

b. 'Kira-kira seminggu yang lalu Mrs Mundy mengalami stroke, sedangkan

(a)

suaminya sakit keras.'

(b)

Datum (24a) describes that the constituents of (a) Mrs Mundy had a stroke about a week ago and (b) the old man's been very ill with pneumonia show additive relationship, that is the situation of Mrs. Mundy having stroke added by the condition of her husband having serious illness because of pneumonia. Differently, the equivalence of and in Indonesian is sedangkan, having the relationship meaning of concessive. When the two constituents are analyzed, the use of sedangkan here, is not appropriate. To get the same relationship meaning, the translator 
should have used ditambah lagi / tambahan lagi/ dan. It seems that the relationship meaning of and is comprehended in discourse relationship. So, prior knowledge of the translator on the discourse influences the equivalence of and she uses in Indonesian.

The following has another expression.

25. a. The past was going to bury its dead and the future was bright and golden.

b. 'Masa lampau sudah mati dan dihabisi, dan masa depan mereka gemilang, penuh warna keemasan.'

The equivalence of the structure of the construction with and in data (25) in Indonesian is not fully the same. Eventhough the two kinds of constructions have two ands and two dans, in the first clause of the Indonesian data, the marker dan is on sudah mati dan dihabisi which cannot be found in the first clause of the English data, and in the second clause there is no and equivalence. It means that the construction without and can be expressed in the construction with conjunctive marker in Indonesian and vice versa. While the relationship meaning of and in sentence 25 a is sequencial.

\section{Conclusion}

Based on the construction and the relationship meaning of the constituents connected, and has various equivalence expression in Indonesian. As its generic meaning, and is mostly equal to dan in Indonesian. Then, it is followed by constructions without its equivalence (zero marker) in the Indonesian expression. The equivalence of the constructions with and in Indonesian may be identical and different. The examples of different constructions are the use of and in active transitive construction in English becomes passive transitive construction in Indonesian, and the combination of prepositional phrases with and in English is found as the sentence combination with yang juga in Indonesian. The equivalence expression of the relationship meaning of and in Indonesian may be the same and different. The example of the different one is that and is expressed with zero marker in the Indonesian expression, and the relationship meaning of emphatic may change into the relationship meaning of terminative. Other equivalences of and are lalu, kemudian, untuk, baik ... maupun, sedangkan, bahkan, akibatnya, sedangkan, namun, sehingga, juga, tepat, karena. The equivalence of the construction with and, its relationship meaning and its semantic function in Indonesian is shown in Table 2.

\section{References}

Alwi, Hasan. (1992). Modalitas dalam bahasa Indonesia. Yogyakarta: Kanisius, (Chapter 4).

Alwi, Hasan et. al. (2003). Tata bahasa baku bahasa Indonesia. Jakarta: Pusat Bahasa, (Chapter 6).

Baker, C.L. (1996). English syntax. Cmbridge: Library of Congress Cataloguing-in-Publication Data, (Chapter 16).

Berk, Lynn M. (1998). English syntax: From word to discourse. New York: Oxford University Press, (Chapter 8).

Biber, Dauglas, et al. (1999). Longman grammar of spoken and written English. Harlow: Pearson Education Limited, (Chapter 15).

Comrie, Bernard. (1989). Language universal and linguistics typology. Chicago: The University of Chicago Press, Chapter (7).

Djajasudarma, T. Fatimah. (1993). Metode linguistik: Ancangan metode penelitian dan kajian. Bandung: Eresco, (Chapter 3).

(1994). Wacana. pemahaman dan hubungan antarunsur. Bandung: PT Eresco, (Chapter 4).

(2002). Analisis bahasa: sintaksis dan semantik. Bandung: Humaniora Utama Press, Chapter 3).

Dik, Simon. C. (1972). Coordination. its implication for the theory of general linguistics. Amsterdam: North-Holland Publishing Co, (Chapter 5).

Dick, Simon.C. (1980). Studies in functional grammar. New York: Academic Press Inc, (Chapter 9).

Fries, Peter H. (2002). Some aspects of coherence in a conversation in Relations and functions within and around language pp.346-375. Ed. Fries, Peter H. et. al. London: NPG Books Ltd.

Gianto, A.G. (1983). Konjungsi dan, atau, tetapi: Kajian sintaktis dan semantis. Yogyakarta: Penerbit Kanisius (Chapter 4). 
Givon, T. (1984, 1990). Syntax. a functional typological introduction, Vol. II. Amsterdam: John Benjamin Publishing Company, (Chapter 19).

Halliday, M.A.K. (1990). An introduction to functional grammar. Singapore: St. Edmundsbury Press Ltd, ( Chapter 7).

Halliday, M.A.K dan Matthlessen, Christian M.I.M. (1999). Construing experience through meaning: A language-based approach to cognition. Cornwell: T.J International, Ltd.

Halliday, M.A.K. (2002). Linguistic Studies of Text Discourse. London: British Library Cataguing-in-Publication Data, (Cahpter One).

Huddleston, Rodney. (1998). English grammar: an outline. Cambridge: Cambridge University Press, Chapter 5).

Huddleston, Rodney et al. (2002). Coordination and Supplementation, pp. 1273-1361 Ed. Huddleston, Rodney.

Vol. 2. Cambridge: Cambridge University Press.

Kyratzis, A dan S. Ervin-Tripp. (1999). The development of discourse markers in peer interaction. Journal of pragmatics, Vol. 7, No. 1, pp. 1321-1338.

Martin, J.R. (1992). English text: system and structure. Amsterdam: John Benjamins Publishing Company (Chapter 8).

Martin, J.R., et al. (1997). Working with functional grammar. New York: St. Martin Press, Inc., (Chapter 9).

Maurer, Jay. (2000). Focus on grammar. An advanced course for reference and practice. New York: Pearson Education Company, (Chapter 6).

Murcia, Marianne-Celce \& Larsen-Freeman, Diane. (1999). The grammar book: An ESL/EFL teacher's course. New York: Heinle \& Heile Publishers, (Chapter 22, 23).

Pullum, Geoffrey K. \& Huddleston, Rodney. (2002). Prepositions and Prepositional Phrases, pp. 597-661, Ed. Huddleston, Rodney. Vol. 1. Cambridge: Cambridge University Press, Chapter.

Quirk, Randolph et al. (1987). A Comprehensive grammar of the English language. New York: Longman, Inc., (Chapter 12, 13).

Rusdi. (2000). Information sequence structure in seminar discourses: A comparative study of Indonesian and Australian students in academic settings. Unpublished Dissertation. Curtin Unversity of Technology, Perth. Australia.

Schiffrin, Deborah. (1992). Discourse markers. Cambridge: Cambridge University Press, (Chapter 10).

Seliger, Herbert W. \& Shohamy, Elana. (1989). Second language research methods. Oxford: Oxford University Press, (Chapter 7).

Song, Jae Jung. (1996). A universal-typological perspectives. London: Longman. [Online] Available: http://www.hamminkj.cafeprogressive.com.htm (March 14, 2003).

Sugono, Dendi. (1995). Pelesapan subjek dalam bahasa Indonesia. Jakarta: Pusat Pembinaan dan Pengembangan Bahasa, (Chapter 5).

- (2004). "Orisinalitas gagasan dalam penulisan tesis dan disertasi" dalam Batas bahasaku batas duniaku. Bandung: PT. Alumni, (Chapter 5).

Talmy, Leonard. (1978). Subordination and coordination. In Greenberg, Joseph H (Eds.), Universals of human language syntax. (pp. 489-513). Vol. 4. Stanford: Stanford University Press.

Teschner, Richard V., \& Evans, Eston. (2000). Analyzig the grammar of English.(2 ${ }^{\text {nd }}$ ed.) Washington, D.C.: Georgetown University Press, (Chapter 8). 


\section{The list of Symbol}

$$
\begin{array}{crllll}
\mathrm{S}=\text { subject, } & & \mathrm{V}=\text { verb, } & & \text { Con. } & \text { = conjunction } \\
\mathrm{O}=\text { object, } & \mathrm{C} & =\text { complement, } & \text { Cond. } & \text { conditional } \\
\mathrm{A}=\text { adverbial }, & \mathrm{PP} & =\text { prepositional phrase } & \text { InfP. } & \text { = infinitive Phrase }
\end{array}
$$

Log.Op. $=$ logical Operator $\quad$ VP $=$ verb Phrase $\quad N P=$ noun phrase

$\mathrm{CCL}=$ coordinating clause $\quad \mathrm{SCL}=$ subordinating clause $\quad$ Stc. $=$ sentence

cop. $=$ copular $\quad$ part. $=$ particle $\quad$ det. $=$ determiner

\begin{tabular}{|c|c|c|}
\hline \multicolumn{2}{|c|}{ The Variation Form of AND } & \multirow[b]{2}{*}{ Indonesian Equivalence } \\
\hline English AND & Indonesian & \\
\hline \multirow{4}{*}{ Coordinator } & Coordinator & $\begin{array}{l}\text { dan, atau, tetapi/tapi, di samping, sementara, sekaligus, } \\
\text { kemudian, serta, baik ... maupun, bercampur, apalagi }\end{array}$ \\
\hline & Subordinator & sedangkan, sambil, sehingga \\
\hline & $\begin{array}{l}\text { Conjunctive } \\
\text { Adverbial }\end{array}$ & namun, demikian juga, akhirnya, akibatnya, dengan demikian \\
\hline & Preposition & untuk, dengan \\
\hline
\end{tabular}

aux. = auxiliary

Table 1. The variation form of AND in English and in Indonesian as well as its equivalence

\begin{tabular}{|c|c|c|c|}
\hline \multicolumn{2}{|c|}{ The Construction } & \multicolumn{2}{|c|}{ The Meaning and Function } \\
\hline $\begin{array}{l}\text { Identical } \\
\text { (English-Ind.) }\end{array}$ & $\begin{array}{l}\text { Different } \\
\text { (English-Ind.) }\end{array}$ & $\begin{array}{l}\text { Identical } \\
\text { (English-Ind.) }\end{array}$ & $\begin{array}{l}\text { Different } \\
\text { (English-Ind.) }\end{array}$ \\
\hline $\begin{array}{l}\text { Phrase-Phrase } \\
\text { Clause-Clause } \\
\text { Passive-passive } \\
\text { And-dan, lalu }\end{array}$ & $\begin{array}{l}\text { Phrase-Clause } \\
\text { Clause-Sentence } \\
\text { Active-Passive } \\
\text { And-without dan }\end{array}$ & $\begin{array}{l}\text { Cond.- Cond. } \\
\text { Additive-Additive } \\
\text { Log.Op. -Log.Op. }\end{array}$ & $\begin{array}{l}\text { Emphatic- Cond. } \\
\text { Emphatic-Terminative } \\
\text { Additive-Consessive }\end{array}$ \\
\hline
\end{tabular}

Table 2. The pofrile of the expression of And in Indonesian 